\title{
DEFINISI KATA CANTIK: ANALISIS KOLOKASI
}

\author{
Indirawati ZAHID \\ Akademi Pengajian Melayu, \\ Universiti Malaya, 50603 Kuala Lumpur \\ indirawati@um.edu.my
}

Manuscript received 12 February 2018

Manuscript accepted 13 June 2018

\begin{abstract}
ABSTRAK
Kamus hanya memberikan definisi kata cantik secara umum. Bagi memperoleh makna kata cantik, domain semantik kata cantik akan dianalisis. Analisis domain semantik ini akan memperlihatkan kolokasi kata yang berlaku. Analisis yang dilakukan berfokus pada kolokasi kata cantik yang dirujuk pada wanita dan menggunakan iklan tempatan produk kecantikan wanita sebagai data. Data diperoleh daripada pelbagai bentuk media. Analisis yang dilakukan menggunakan empat metod, iaitu kajian pustaka, syot layar, analisis teks dan kuantitatif. Dapatan analisis antaranya memperlihatkan definisi kata cantik untuk wanita tempatan: kulit - cerah, gebu, putih, $\varnothing$ parut jerawat, $\varnothing$ kering; bentuk badan - langsing; bibir berwarna merah, $\varnothing$ kering; rambut - lebat, hitam, harum; kuku - kuat, iaitu tidak mudah patah; dan telapak kaki dan tumit - lembut, $\varnothing$ kering, harum. Sifat-sifat yang bertentangan pula dianggap sebagai tidak cantik. Dapatan ini memperlihatkan bahawa makna cantik berkaitan dengan tiga deria, iaitu rasa, lihat dan bau. Analisis ini menunjukkan definisi kata "cantik" diterangkan dari perkataan yang digunakan secara bersama - kolokasi.
\end{abstract}

Kata kunci: iklan, wanita, semantik, domain, kolokasi.

THE DEFINITION OF THE WORD “CANTIK": COLLOCATION ANALYSIS

\begin{abstract}
Dictionary only gives the definition of the word "cantik" in general. To get the meaning of the word "cantik", the semantic domain of the word "cantik" was analysed to show the collocations. This analysis focused on the collocation of the word "cantik" related to women and had used local advertisements of women's beauty products as data. Data were collected from various forms of media. Four methods were applied: library research, screen shot, text analysis and quantitative analysis. Findings shows the definition of the word "cantik" according to local
\end{abstract}


women are: skin - fair, soft, white, clear from acne scars, $\varnothing$ dry; body shape - slim; lips - red, $\varnothing d r y$, ; hair - thick, black, fragrant; and nails - strong, nails that are not easily broken; and sole and heels $-\varnothing d r y$, fragrant, soft. Opposite attributes are not considered "cantik". These findings show the meaning of the word "cantik" related to three senses; i.e touch, sight and smell. Thus, this analysis shows the definition of the word "cantik" was elaborated from collocated words.

Keywords: advertisement, women, semantic, domain, collocation.

\section{Pendahuluan}

Kata cantik dikolokasikan dengan manusia yang bergender wanita. Selain berkolokasi dengan wanita, kata cantik juga boleh berkolokasi dengan kata pemandangan, baju, rumah dan banyak lagi objek yang lain. Walau bagaimanapun kata cantik tidak berkolokasi dengan gender lelaki, iaitu gender yang bertentangan dengan wanita. Sebaliknya kata lelaki berkolokasi dengan kata tampan dan kacak. Cantik secara umumnya merujuk pada pandangan mata yang selesa dilihat atau dalam bahasa percakapan dikatakan "sedap" mata memandang. Kamus Dewan (2015) mendefinisikan kata cantik sebagai:

Cantik I sangat menarik apabila dipandang (bkn orang perempuan, rupa muka, bangunan, benda, pemandangan, dII), sangat elok (bagus, molek); gadis yang ; barang-barang perhiasan yang ; bagaimanapun nya satusatu rancangan, tidak akan berjaya jika tidak diturut kehendak rancangan itu dgn ikhlasnya. (245)

Definisi kamus ini telah secara umum menjelaskan makna cantik dalam bahasa Melayu. Sungguh pun begitu, definisi umum ini tidak begitu membantu pelajar bahasa (bahasa kedua mahupun asing) apabila diminta memberikan fitur yang dikatakan cantik ataupun memperkatakan tentang keadaan cantik yang dirujuk. Paparan definisi kata cantik yang diberikan tidak memperlihatkan penghuraian terperinci tentang fitur makna kata ini. Selain tidak mempunyai penghuraian tentang fitur atau ukuran yang ditetapkan atau ditentukan, kolokasi yang ada juga bersifat terhad. Kesedaran tentang kekurangan rujukan makna kata ini telah menarik para pengkaji untuk melakukan kajian dari pelbagai aspek dan bidang.

Beberapa kajian telah menghuraikan definisi kata cantik bagi mendapatkan makna yang dirujuk oleh kata ini. Antaranya ialah Mohd Salleh dan Musa (2016), Wirasari (2016), School of Physical Sciences (2015), Goldman dan Waymer (2014), Shabudin dan Aman (2013a, 2013b), Sidik (2012), Zahid dan Sidik (2012), Britton (2012), Berry (2007) dan Etcoff, Orbach, Scott, dan D'Agostino (2004).

Kata cantik dengan merujuk pada sifat awet muda dari sudut makna konteks dan makna literal telah dilakukan oleh Mohd Salleh dan Musa (2016). Dapatan kajian tersebut memperlihatkan penggunaan frasa awet muda merujuk pada pengekalan usia atau umur, bahan atau benda untuk mengekal sesuatu, rupa paras dan kaedah. Sementara dapatan Wirasari (2016) memperlihatkan bahawa kecantikan wanita bersifat pelbagai. Kepelbagaian ini bermaksud kecantikan tidak hanya pada rupa 
paras tetapi juga kecantikan warna kulit, tubuh, rambut dan sebagainya. Kajian beliau menggunakan data iklan kecantikan wanita Indonesia yang memaparkan dapatan bahawa penampilan wanita Indonesia yang mempunyai warna kulit coklat, iaitu kecantikan khas wanita Indonesia merupakan unsur persuasif dalam menarik khalayak sasaran mereka membeli produk yang dijual. Menurut Wirasari (2016) lagi trend kecantikan umumnya dipengaruhi oleh latar belakang sosial budaya sesuatu masyarakat.

Pasukan penyelidik dari School of Physical Sciences (2015) yang diketuai oleh Dr. Solomon cuba menghuraikan definisi kata cantik bagi wanita dan lelaki. Kajian ini menggunakan teknologi EFIT-V Photofit. Menurut laman sesawang ini, program tersebut dicipta oleh syarikat Solomon yang bernama VisionMetric. Difahamkan program yang sama juga digunakan oleh jabatan polis seluruh dunia untuk membantu mengenal pasti individu yang dikehendaki (wanted individuals). Perisian tersebut menyediakan kepada penggunanya sejumlah wajah yang kemudiannya akan dipilih satu berdasarkan kemiripan. Perisian ini kemudian menggunakan algoritma genetik untuk menjana lebih banyak wajah dengan karakteristik yang hampir dengan wajah yang dipilih tadi dan pengguna akan melakukan pemilihan lagi. Ini berlaku secara berterusan sehingga pemadanan wajah yang paling hampir ditemui, dengan titik fitur individu masih boleh diubah lagi oleh pengguna. Kajian ini didanai oleh Samsung untuk pelancaran telefon Galaxy S6. Kajian ini berlangsung selama dua bulan dengan menggunakan kaedah bertanya kepada orang ramai tentang definisi wajah yang sempurna. Dapatan ini kemudiannya dinilai fitur daya tarikan wajah yang sempurna itu dengan melibatkan lebih daripada 100 orang. Secara ringkas, wanita yang cantik rupa parasnya dikatakan memiliki antaranya bentuk muka yang runcing, bibir penuh, bermata besar, mempunyai tulang pipi yang tinggi; manakala bagi lelaki pula dirujuk pada penampilan yang maskulin. Dapatan kajian ini hanya teraplikasi di England sebagaimana yang dinyatakan oleh penyelidiknya. Dan diakui bahawa setiap kelompok masyarakat mempunyai definisi mereka sendiri apabila merujuk pada makna kata cantik. Penyataan oleh kumpulan penyelidik ini selari dengan penyataan Plato Beauty lies in the eyes of the beholder. Dalam bahasa yang mudah, cantik itu bersifat subjektif.

Sementara itu, Goldman dan Waymer (2014) memetik satu kajian yang dilakukan oleh Berry (2007) yang menyatakan bahawa media membantu dalam membicarakan standard cantik melalui imej-imej yang dipaparkan kepada masyarakat dengan model, aktor, aktres dan individu dalam media yang mempamerkan karateristik yang sama, iaitu tinggi, langsing, kulit yang berseri (radiant skin), muda dan lain-lain lagi. Goldman dan Waymer (2014) dalam perbincangan mereka membahagikan kecantikan kepada dua perspektif yang berbeza, iaitu kecantikan dalaman dan luaran. Kecantikan dalaman menurut mereka merujuk pada fitur-fitur seperti mudah mesra, sopan, mempunyai personaliti yang baik, bijak dan mempunyai sikap yang baik atau terpuji. Sementara kecantikan luaran pula dikatakan memiliki fitur-fitur seperti langsing (kurus yang berkaitan dengan berat badan), tinggi, badan yang "berbentuk" dan kecantikan asli tanpa penggunaan bahan kosmetik yang berlebihan.

Kajian dalam bidang bahasa dan linguistik pula tertumpu antaranya pada penggunaan kata dalam iklan kecantikan, analisis semantik leksikal slogan, 
penggunaan kata kerja dan sebagainya. Shabudin dan Aman (2013a) menghuraikan tentang wacana iklan yang tidak terikat dengan satu genre bagi menggambarkan produk kosmetik kecantikan tetapi telah disatukan dengan pelbagai genre lain yang bersifat saintifik dan farmaseutikal. Dalam kajian kedua mereka (Shabudin \& Aman, 2013b), huraian tertumpu pada ideologi tersirat dalam wacana iklan produk kecantikan berbahasa Jepun berasaskan gabungan teks, semiotik dan sifat kewacanaan. Walaupun huraian dan analisis berfokus pada teori linguistik, apa yang menarik definisi cantik bagi masyarakat Jepun menurut kajian tersebut telah berkiblatkan barat. Wanita Jepun dikatakan berhasrat untuk cantik dengan pemilikan fitur seperti hidung yang mancung, kelopak mata yang berganda (double eyelid), mata yang bulat dan besar, bulu mata yang lebat, panjang serta cantik, bibir yang mungil, rambut yang perang muda dan ikal, kulit putih dan licin serta kaki yang panjang dan lurus. Fitur-fitur cantik ini agak bertentangan dengan fitur wanita Jepun secara umumnya, iaitu kebanyakan mereka tidak tinggi, tidak memiliki mata yang besar dan tidak mempunyai kelopak mata yang berganda.

Sidik (2012) mengkaji penggunaan kata kerja dalam slogan iklan menggunakan kaedah analisis komponen makna bagi menghuraikan kecenderungan penggunaan kata kerja dalam slogan iklan produk kecantikan wanita. Antara dapatan kajian ini ialah penggunaan kata mencerah, menghaluskan, menegangkan, dan menganjal, iaitu kata kerja yang bersifat spesifik dengan kolokasinya memanifestasikan erti kecantikan kepada wanita. Berdasarkan kajian yang dilakukan dapat dilihat bahawa penghasilan produk kecantikan wanita bertujuan membantu wanita mendapatkan fitur kulit yang cerah (putih), halus (tidak kasar atau mengerutu), tegang (tidak kendur), dan anjal, iaitu kenyal. Sifat-sifat ini dianggap antara fitur cantik bagi wanita. Hal yang sama juga dibincangkan oleh Zahid dan Sidik (2012).

Dari sisi yang lain, Britton (2012) membicarakan aspek kecantikan dari perspektif pengaruh industri kecantikan terhadap wanita. Britton (2012) menyatakan terdapat sejumlah kajian yang telah dilakukan atas kesan iklan fesyen dan kecantikan pada wanita. Menurut beliau penciptaan iklan dengan satu imej yang tidak realistik tentang kecantikan telah menimbulkan perasaan kebimbangan/cemas (anxiety), hina diri (low self-esteem) dan kekurangan rasa yakin diri (low self-confidence) dalam kalangan wanita. Menurut beliau lagi kebanyakan emosi negatif ini berpunca daripada perasaan tidak gembira pada tubuh dan penampilan. Britton (2012) juga menyatakan terdapat banyak kajian yang membuktikan bahawa wanita menggunakan kosmetik untuk mempertingkat daya tarikan yang mereka miliki selain meningkatkan rasa yakin diri dan imej diri. Sementara itu, Etcoff et al., (2004) mendapati penampilan fizikal, iaitu wajah, berat badan dan bentuk badan diambil kira dalam fitur kecantikan wanita. Walau bagaimanapun kajian ini juga merangkumkan kegembiraan, kebaikan, kebijakan, maruah, kasih sayang, keaslian dan kesedaran diri sebagai fitur kecantikan juga.

Kajian yang dilakukan sama ada kajian bersifat ilmiah bahasa/linguistik atau kajian yang bertujuan komersial yang ditaja oleh syarikat-syarikat pengeluar produk dan barangan teknologi memperlihatkan bahawa kajian dalam mendapatkan definisi kata cantik merupakan antara agenda penting dalam bidang masing-masing. Kajian yang sedia ada tentang definisi cantik dari perspektif wanita Melayu hanya dilakukan 
oleh Mohd Salleh dan Musa (2016), Sidik (2012), Zahid dan Sidik (2012). Ini membuktikan kajian dalam aspek ini masih lagi kurang.

\section{Domain Semantik dan Kolokasi}

Domain semantik atau medan makna (semantic field) merujuk pada kawasan makna yang spesifik, terkandung di dalamnya sejumlah kata yang berkongsi komponen makna yang sama. Menurut Matthews (2007), domain semantik ialah "a distinct part of the lexicon defined by some general term or concept" (hlm. 360) dengan memberikan contoh warna hitam dan merah yang tercakup dalam domain semantik kata warna. Contoh yang diberikan ini memperlihatkan domain semantik kata warna yang mempunyai sejumlah kata yang berkongsi komponen yang sama, iaitu memiliki rona-rona seperti hitam, putih, biru, merah dan banyak lagi. Kesemua rona-rona ini berkongsi komponen makna yang sama, iaitu memiliki [+rona-rona asas tertentu].

Kata-kata yang terkandung dalam domain semantik berfungsi memerikan makna sesuatu leksikal melalui perkongsian sekurang-kurangnya satu komponen makna bersama. Misalnya, domain semantik kata "manusia" akan mempunyai sejumlah kata di dalamnya, iaitu lelaki, wanita, kanak-kanak, orang tua, orang muda dan sebagainya. Kesemua kata ini memperlihatkan hubungan kata yang lazim digunakan secara bersama dan sekali gus memerikan makna kata "manusia" yang berkongsi komponen makna bersama tersebut. Kesemua kata itu mempunyai fitur yang dimiliki secara bersama, iaitu kata "lelaki" memiliki fitur [+hidup] [+manusia] [+ akal] [-perempuan] [+bapa]; kata "wanita" memiliki fitur [+hidup] [ +manusia] [+akal] [-lelaki] [+melahirkan] dan sebagainya. Kata lelaki dan wanita berkongsi komponen makna yang sama [+manusia] [+hidup] dan [+akal]. Sehubungan dengan itu kata lelaki dan wanita berada dalam domain semantik yang sama, iaitu "manusia" (Zahid, 2017, hlm. 40).

Begitu juga, domain semantik kata "universiti" mempunyai sejumlah kata di dalamnya, iaitu fakulti, dekan, pensyarah, mahasiswa/i, perpustakaan, bilik seminar, dewan peperiksaan dan sebagainya yang memperlihatkan hubungan kata yang lazim digunakan secara bersama-sama dan berkongsi komponen makna bersama. Ini bererti apabila makna kata universiti dihuraikan maka fitur makna yang akan menerangkan makna universiti ini ialah fakulti, dekan, mahasiswa/i, perpustakaan, bilik seminar dan dewan peperiksaan. Kata-kata yang tercakup dalam domain semantik memperlihatkan hubungan kata sama ada secara kolokasi, iaitu kata yang lazim digunakan secara bersama ataupun secara paradigma misalnya antonimi, sinonimi dan sebagainya. Hubungan secara paradigma diperlihatkan melalui perbezaan yang wujud misalnya antara kata perpustakaan dan dewan peperiksaan; mahasiswa dan mahasiswi; pensyarah dan pelajar dalam domain semantik kata universiti dan perbezaan gender lelaki dan perempuan dalam domain semantik manusia. 
Bertitik tolak daripada hubungan kata yang pertama, iaitu kata yang lazim digunakan secara bersama-sama, domain semantik kata cantik bagi wanita akan dianalisis. Seperti yang dinyatakan lebih awal, definisi kata cantik dalam kebanyakan kamus hanya secara umumnya mendeskripsikan makna kata cantik sebagai hasil pandangan mata yang menyenangkan, iaitu sesuatu yang indah apabila dilihat (rujuk definisi kamus yang diberikan dalam perbincangan awal). Deskripsi yang sebegini bersifat umum tanpa dinyatakan fiturnya secara terperinci. Sehubungan itu, sebagai seorang pelajar bahasa bagaimanakah akan dapat difahami dan diperoleh fitur-fitur makna kata cantik ini? Fitur-fitur makna kata cantik ini akan hanya dapat diperoleh apabila merujuk pada tafsiran makna kata cantik yang digunakan oleh penutur natif. Dalam konteks makalah ini, domain semantik kata cantik yang berkolokasi dengan wanita akan diperlihatkan melalui analisis pada slogan/motto dan ayat yang digunakan oleh pengeluar produk kecantikan dalam iklan produk kecantikan mereka. Bersandarkan penghuraian tentang khasiat produk kecantikan, kolokasi kata cantik berdasarkan penutur natif dapat diperoleh. Kolokasi kata inilah yang memberikan definisi sebenar kata cantik dalam kalangan wanita menurut perspektif penutur natif bahasa Melayu. Secara umumnya domain semantik kata cantik mencakupi bahagian-bahagian tubuh seseorang wanita seperti dalam Rajah 1 yang berikut:

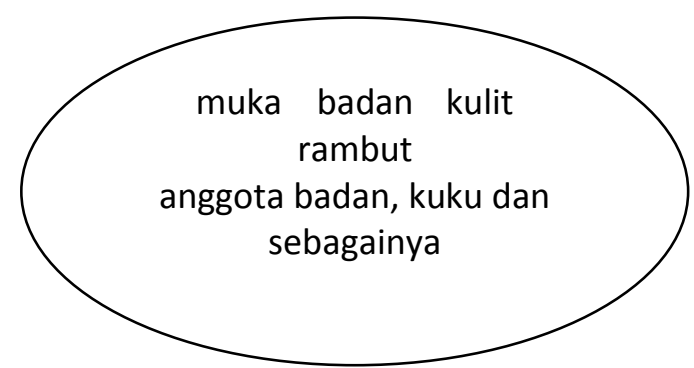

Rajah 1: Domain semantik kata cantik - wanita

Setiap satu kata yang menjadi ahli dalam domain semantik kata cantik bagi wanita ini mempunyai kolokasinya yang tersendiri bagi menjelaskan fitur kata cantik yang dirujuk. Misalnya, bahagian muka yang dianggap cantik antaranya akan memiliki fitur bersih, putih, $\varnothing$ jerawat; kecantikan rambut pula akan memiliki antaranya fitur lebat, berwarna hitam serta bersinar dan sebagainya. Dan cantiknya seorang wanita itu lazimnya dilihat dari hujung rambut sehingga ke hujung kaki, iaitu mencakupi muka, badan, kulit, rambut, anggota badan, kuku dan sebagainya.

Pengetahuan tentang makna kata dan kolokasi merupakan satu kompetensi yang diperlukan bagi pelajar bahasa. Menurut Channell (1981) kompetensi menghubungkan kata secara kolokasi merupakan satu asas yang baik dalam memperluas pemahaman tentang kosa kata. Hal yang sama juga dibincangkan oleh Webb dan Kagimoto (2009) yang mengakui bahawa dalam mempelajari bahasa bagi pelajar bahasa kedua, pengetahuan tentang kolokasi merupakan aspek yang penting sepertimana juga dinyatakan oleh Bahns dan Eldaw (1993), Howarth (1998), Lewis (2000), McCarthy dan O'Dell (2005) dan Nesselhauf (2003). Dalam konteks ini, kamus ternyata mempunyai peranan yang terhad. Penyataan ini tidak bermaksud 
menyatakan bahawa kamus telah gagal dalam membantu pelajar bahasa. Kamus tidak boleh dipersalahkan kerana fungsi kamus walaupun bertujuan untuk pembelajaran bahasa tetapi kapasiti kamus untuk menjadi bahan rujukan pembelajaran bahasa yang bersifat mutlak tidak mungkin berlaku. Ini kerana peranan kamus antara lainnya hanya merujuk pada penyenaraian sejumlah kosa kata yang terdapat dalam sesuatu bahasa (pendokumentasian kosa kata), memberikan makna kata, membezakan makna kata, etimologi kata (tidak semua kamus membekalkan maklumat ini), cara penyebutan (tidak semua kamus membekalkan maklumat ini), iaitu penyediaan transkripsi fonetik, memaparkan penggunaan kata secara ringkas dan sebagainya. Sehubungan dengan itu, fungsi kamus didapati terhad seperti paparan definisi kata cantik yang diberikan sebelum ini. Seandainya sesebuah kamus membekalkan kesemua maklumat kosa kata secara terperinci, ketebalan sesebuah kamus mungkin tidak dapat dibayangkan. Lanjutan itu untuk mempelajari definisi kata dan fitur makna kata yang dirujuk, pelajar bahasa perlu mempelajarinya daripada penutur natif sesuatu bahasa dan melihat bagaimana kata ini digunakan dalam konteks linguistiknya. Menurut Richards (1976), pengetahuan tentang makna sesuatu kosa kata antara lainnya bererti mengetahui kekerapan penggunaannya, kesesuaian penggunaannya berdasarkan konteks, pembentukan katanya dan fitur semantiknya dan ini tentulah hanya dapat diketahui melalui penutur natif sesuatu bahasa.

\section{Objektif Kajian}

Kajian ini mempunyai dua objektif seperti yang berikut:

1. Mengenal pasti kata-kata yang digunakan untuk mendefinisikan kata cantik - wanita.

2. Menganalisis kolokasi kata dalam domain kata cantik - wanita.

\section{Metodologi}

Kajian ini menggunakan data iklan bahasa Melayu, iaitu produk kecantikan wanita keluaran syarikat tempatan. Data dikumpulkan dari pelbagai media, iaitu teks iklan dari majalah, laman sesawang syarikat produk kecantikan, iklan di instagram (ig) dan sebagainya yang relevan. Bahan kajian berfokus pada produk kecantikan D'Herbs serta Vida Beauty dan produk kecantikan Aura White sebagai data sokongan. Data dikumpulkan daripada slogan/motto dan ayat yang digunakan dalam iklan produk kecantikan kedua-dua jenama ini. Data berfokus pada kecantikan muka, tubuh dan anggota badan yang lain. Jumlah keseluruhan data yang dianalisis berjumlah 205 kata yang berkolokasi, masing-masingnya mewakili 114 kulit (muka), 20 telapak kaki dan tumit, 18 bibir, 31 rambut, 17 badan/anggota badan lain dan 5 kuku.

Kajian akan hanya menggunakan data dari iklan produk kecantikan wanita keluaran usahawan tempatan di Malaysia. Data hanya menggunakan slogan/motto dan ayat yang dipaparkan dalam bahasa Melayu. Walau bagaimanapun kata-kata bahasa Inggeris yang lazim digunakan secara campur kod (code mixing) misalnya kata glowing, flawless, radiant tetap diambil sebagai data kajian. 
Kajian ini mengaplikasikan empat metod, iaitu kajian pustaka, syot layar, analisis teks dan kuantitatif. Kajian pustaka melibatkan pengumpulan bahan kajian yang lepas untuk mendapatkan gambaran dan trend kajian yang bersifat semasa tentang skop kajian, iaitu kecantikan wanita. Syot layar pula merujuk pada proses penangkapan (capture) data dari sumber sesawang atau media di internet. Terdapat juga data-data yang dapat dikumpul dari laman sesawang syarikat produk kecantikan dan bentuk teks dari majalah tempatan. Sementara analisis teks merujuk pada data-data yang dikumpulkan akan disisih menurut kategori, iaitu sama ada merujuk pada: i. kulit - muka dan badan, ii. telapak kaki dan tumit, iii. bibir, iv rambut, v. badan/anggota badan yang lain dan vi. kuku. Penyisihan data ini akan memudahkan proses menganalisis bagi memperlihatkan hubungan kolokasi dan domain semantik bagi data yang dianalisis. Jumlah data yang terkumpul untuk dianalisis tidak mewakili secara mutlaknya jumlah kolokasi kata. Ini bermaksud wujudnya kebarangkalian sesuatu slogan atau motto itu mempunyai lebih daripada satu kolokasi. Slogan iklan kecantikan kulit muka misalnya mempunyai lebih daripada satu kata yang berkolokasi dalam satu iklan yang sama, iaitu kata cerah, lembut, halus dan sebagainya. Dapatan analisis akan dipaparkan secara kuantitatif dengan peratusan kecenderungan dapatan.

\section{Dapatan dan Perbincangan}

Dapatan dan perbincangan analisis ini dipecahkan kepada beberapa kategori, iaitu kulit (muka); telapak kaki dan tumit; bibir; rambut; badan/anggota badan lain dan kuku. Dapatan analisis yang dilakukan memperlihatkan bahawa penghasilan produk kecantikan wanita cenderung tertumpu pada kecantikan rupa paras seseorang (dengan tidak menafikan kewujudan produk penjagaan kecantikan bentuk badan dan kecantikan dalaman). Khasiat penggunaan produk kecantikan yang dipasarkan ini telah memberikan definisi kata cantik bagi wanita dengan pelbagai fitur yang ditanggap oleh majoriti khalayak.

Dapatan analisis memperlihatkan kecantikan kulit muka, badan dan rambut dikolokasikan kepada dua aspek, iaitu yang pertamanya sifat kulit muka, badan, kaki dan rambut itu sendiri dan yang kedua dirujuk sebagai bersih dengan fitur-fitur bersih yang dirujuk. Manakala kecantikan telapak kaki dan tumit, bibir, rambut, dan kuku memperlihatkan fitur yang terhad.

Paparan definisi kata cantik dan kolokasinya akan dihuraikan berdasarkan bahagian-bahagian yang dianalisis secara satu persatu mengikut urutan (Jadual 1).

\section{Kata mendefinisi kata cantik - muka}

Jadual 1

Kolokasi kata cantik - Muka

\begin{tabular}{llcc}
\hline Bil. & Muka & Jumlah & Peratusan (\%) \\
\hline 1. & Anjal & 6 & 5.3 \\
2. & Gebu & 8 & 7.0 \\
3. & glowing (berseri) & 1 & 0.9 \\
4. & $\varnothing$ garis halus & 5 & 4.4
\end{tabular}


5. halus

6. $\varnothing$ kedut

7. $\varnothing$ kering

1.8

8. $\varnothing$ kusam

1.8

9. lembut

1.8

10. lembab

2.6

11. pejal

0.9

12. segar

0.9

13. sihat

1.8

14. tegang

2.6

15. tona sekata

2.6

16. melambatkan proses penuaan

17. Bersih

$\begin{array}{llcl}\text { i. } & \varnothing \text { parut jerawat } & 10 & 8.8 \\ \text { ii. } & \varnothing \text { jeragat } & 8 & 7.0 \\ \text { iii. } \varnothing \text { bintik hitam/ } & 4 & 3.5\end{array}$

iii. $\varnothing$ bintik hitam/ tompok hitam

iv. $\varnothing$ sel-sel kulit mati

0.9

v. $\varnothing$ berminyak

2.6

vi. $\varnothing$ jerawat

7.0

vii. $\varnothing$ pori-pori

3.5

viii. $\varnothing$ parut

0.9

ix. $\varnothing$ regangan kulit

1.8

$x$ licin

0.9

xi. putih

5.2

xii. cerah

8.8

xiii. $\varnothing$ panau

1.8

xiv. $\varnothing$ berbau

0.9

xv. $\varnothing$ gelap

0.9

xvi. harum

0.9

xvii. $\varnothing$ berdaki

0.9

xviii. Flawless(sempurna) Jumlah

114 100

Petunjuk: $\varnothing$ - tidak mempunyai fitur makna yang dirujuk.

Dapatan kuantitatif di atas memperlihatkan kecantikan kulit (muka) dan fitur bersih dikolokasikan dengan 114 kata, antaranya "anjal", "gebu", "glowing", "cerah" dan sebagainya. Walau bagaimanapun dari sejumlah 114 kata tersebut terdapat beberapa kata yang dominan digunakan apabila dirujuk pada sifat cantik muka yang dirujuk. Kata "cerah" dan " $\varnothing$ parut jerawat" memperlihatkan penggunaan kata yang tertinggi dalam iklan kecantikan muka, masing-masingnya dengan $8.8 \%$. Ini diikuti dengan penggunaan kata "gebu", " $\varnothing$ jeragat" dan " $\varnothing$ jerawat", 7.0\%. Manakala kata "anjal" dan "putih" memperlihatkan penggunaan kata masing-masingnya $5.3 \%$ dan $5.2 \%$. Dalam konteks iklan produk kecantikan, didapati pengeluar produk kecantikan sering kali menggunakan kata "cerah" dan "putih" secara bertukar ganti dalam iklan 
mereka. Kata seperti " $\varnothing$ garis halus", " $\varnothing$ kedut", " $\varnothing$ pori-pori terbuka", "tegang", "tona sekata", "proses penuaan yang lambat" dan sebagainya memperlihatkan penggunaan kata yang kurang dengan jumlah peratusan yang pelbagai dan tidak jauh beza. Peratusan jumlah yang kecil dan tidak banyak bezanya ini tidak bererti penggunaan kata-kata ini tidak signifikan dalam mendefinisikan kata cantik. Sebaliknya slogan dan motto dalam iklan didapati menggunakan mana-mana satu kata yang tersebut secara bertukar ganti kerana cakupan maknanya yang hampir sama, iaitu jika tiada garis halus, ia juga bererti tiada kedutan. Kewujudan garis halus di kulit pada tempoh masa tertentu akan menyediakan ruang untuk kedutan kulit berlaku yang selanjutnya menjejaskan ketegangan kulit muka. Begitu juga apabila adanya pori-pori terbuka pada muka, tona atau warna kulit muka menjadi tidak sekata dan kesemua sifat-sifat yang dinyatakan ini saling berhubungan, iaitu kesan dan akibat. Sekiranya kesemua sifat ini tidak dikawal ia akan mempercepatkan proses penuaan kulit.

Begitu juga sekiranya kata "glowing" dan "flawless" digunakan dalam iklan, maka makna yang dicakupinya oleh kedua-dua kata ini terlalu luas, iaitu berseri dan sempurna yang merujuk pada sifat tidak ada cacat-cela. Sifat berseri dan tiada cacatcela ini akan menimbulkan persoalan. Bagi pengguna produk kecantikan kata "glowing" dan "flawless" ini tidak memenuhi erti kata cantik yang diingini oleh pengguna yang ingin mengetahui tentang kesan sesuatu produk kecantikan itu secara spesifik. Sehubungan itu dalam iklan produk kecantikan dapat dilihat semacam satu penyenaraian khasiat produk yang dipasarkan bagi tujuan menarik pelanggan menggunakan produk sesuai dengan masalah yang mereka hadapi. Penyenaraian khasiat atau kebaikan produk tersebut memberikan definisi kata cantik yang diingini oleh wanita. Lihat contoh iklan D'herbs (Rajah 2) dan Vida Beauty (Rajah 3 dan 4) yang berikut:

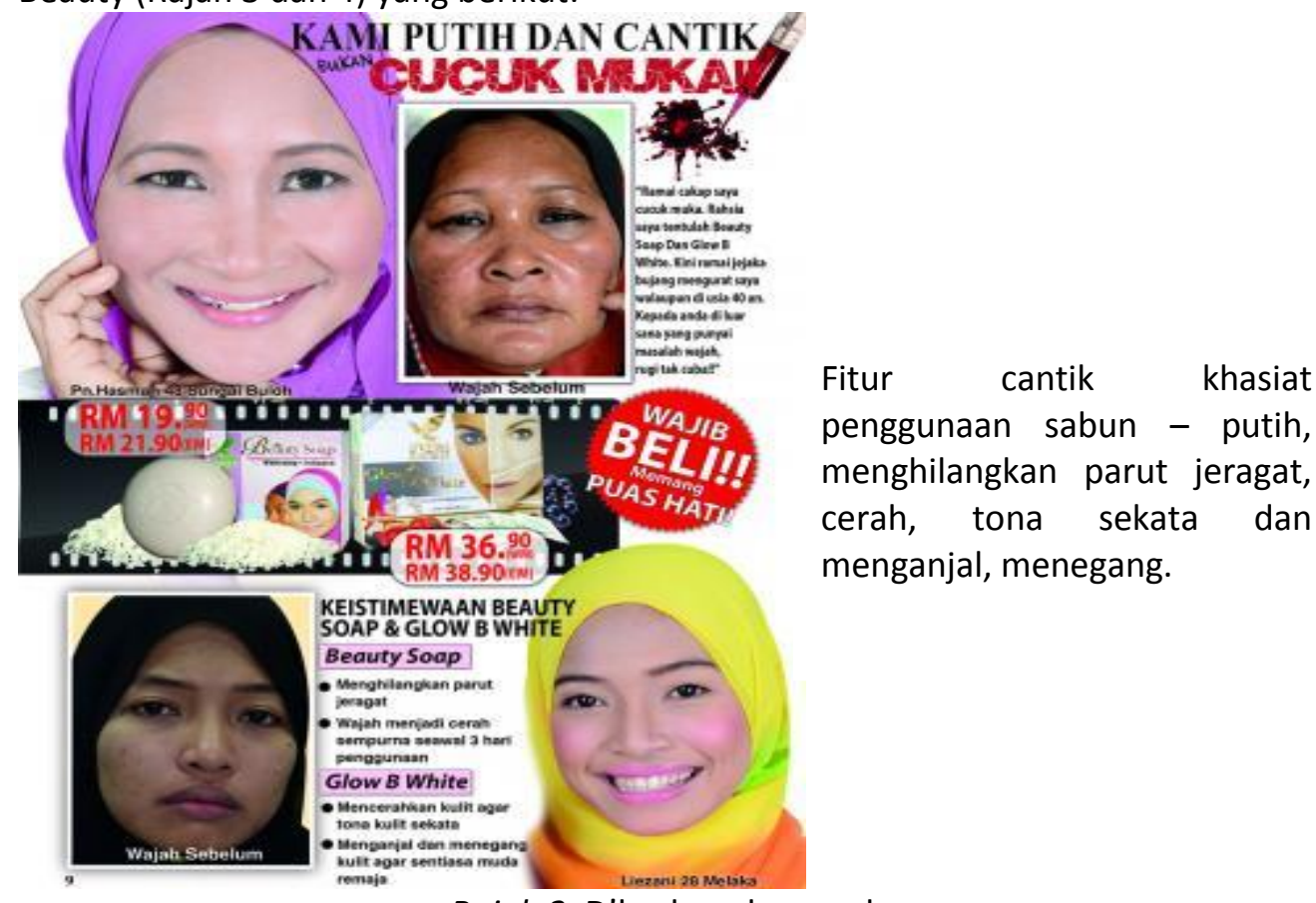

Rajah 2. D’herbs sabun muka 


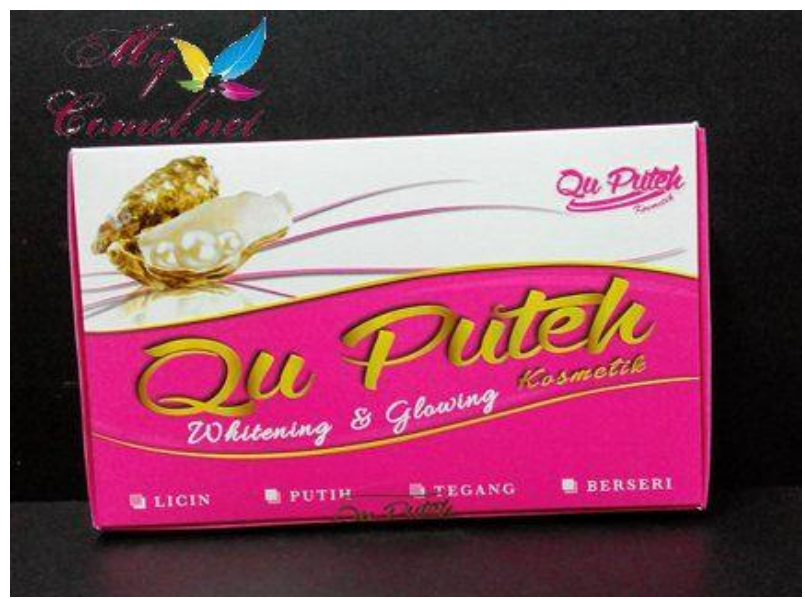

Fitur cantik khasiat penggunaan sabun licin, putih, tegang dan berseri.

Rajah 3. Qu Puteh sabun muka

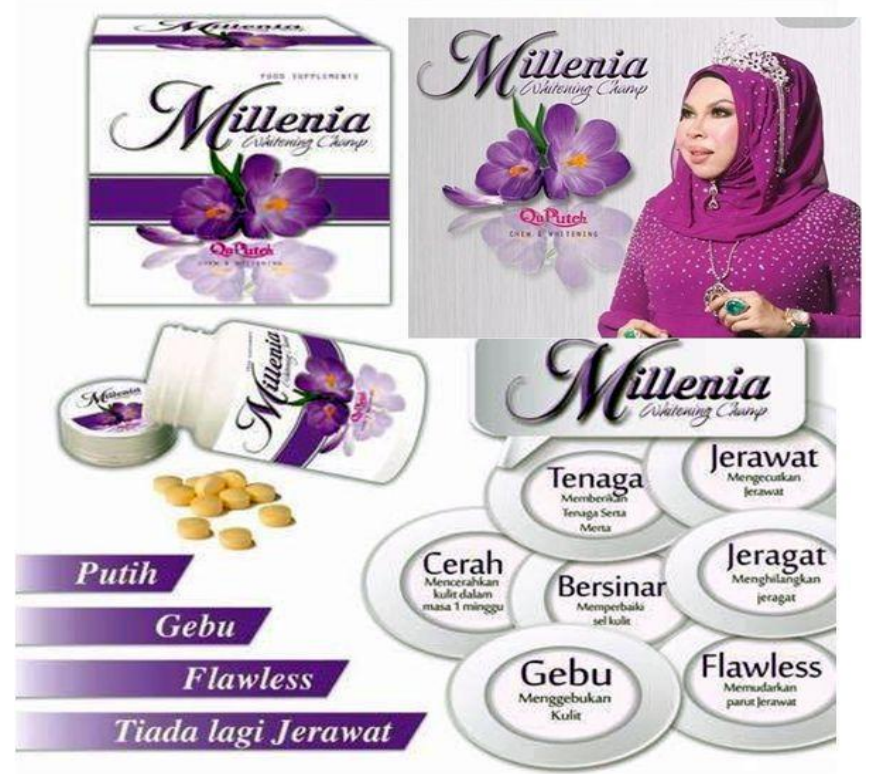

Fitur cantik dengan memakan suplemen:

putih, gebu, cerah, flawless, $\varnothing$ jerawat, menghilangkan jeragat dan bersinar.

Rajah 4. Qu Puteh suplemen

Dapatan kolokasi kata yang tersenarai dalam Jadual 1 tentang kecantikan muka memperlihatkan fitur cantik yang diingini oleh wanita. Paparan kualiti kulit muka yang [+ putih/cerah] [+ licin] [- bau] dianggap bersih. Semua keadaan yang menjejaskan tiga sifat ini dianggap tidak cantik. Lanjutan itu, parut jerawat akan menyebabkan permukaan muka tidak licin, berlubang, tidak rata; kewujudan jeragat, bintik/ tompok hitam menjadikan permukaan kulit bercapuk-capuk dan menjejaskan keputihan atau kecerahan kulit; keadaan kulit berminyak akan menyebabkan kekotoran mudah melekat dan muka menjadi berkilat; keadaan pori-pori terbuka menjadikan kulit muka seperti berlubang-lubang; kulit muka yang berjerawat pula akan menjejaskan kelicinan kulit dan menjejaskan warna kulit yang putih/cerah kerana muka yang berjerawat akan kelihatan bengkak dan merah. Kesemua keadaan ini menjejaskan makna bersih, iaitu tanpa cela pada kulit muka yang dirujuk. 
Kata mendefinisi kata cantik - telapak kaki dan tumit

Jadual 2

Kolokasi kata cantik - Telapak kaki dan tumit

\begin{tabular}{llcc}
\hline Bil. & Telapak kaki dan tumit & Jumlah & Peratusan \% \\
\hline 1. & Lembut & 3 & 15.0 \\
2. & $\varnothing$ keras & 2 & 10.0 \\
3. & $\varnothing$ rosak & 2 & 10.0 \\
4. & Halus & 2 & 10.0 \\
5. & $\varnothing$ kulit mati & 1 & 5.0 \\
6. & $\varnothing$ kasar & 1 & 5.0 \\
7. & $\varnothing$ menggelupas & 1 & 5.0 \\
8. & $\varnothing$ kusam & 1 & 5.0 \\
9. & $\varnothing$ pecah-pecah & 1 & 5.0 \\
10. & $\varnothing$ retak-retak & 1 & 5.0 \\
11. & $\varnothing$ merekah & 1 & 5.0 \\
12. & Segar & 1 & 5.0 \\
13. & $\varnothing$ kering & 1 & 5.0 \\
14. & Lembap & 1 & 5.0 \\
15 & Bersih & & \\
& 1. $\varnothing$ berbau & 1 & 5.0 \\
\hline & Jumlah & 20 & $100 \%$ \\
\hline
\end{tabular}

Petunjuk: $\varnothing$ - tidak mempunyai fitur makna yang dirujuk

Bagi kecantikan telapak kaki dan tumit, Jadual 2 menunjukkan 20 kata yang berkolokasi. Kata "lembut" $15 \%$ secara dominannya digunakan bagi menggambarkan sifat cantik untuk bahagian ini, diikuti dengan kata " $\varnothing$ keras", " $\varnothing$ rosak", "halus" dan " $\varnothing$ kulit mati" masing-masingnya 10\%. Jika diteliti kata "lembut" (Tesaurus Bahasa Melayu Dewan, 2010, hlm. 494) bersinonim dengan "kata tidak keras" yang sekiranya disekalikan jumlah ini dengan kata "lembut", jumlah peratusan meningkat menjadi 25\%. Dan pada masa yang sama kata "lembut" (lihat antonim, Tesaurus Bahasa Melayu Dewan, 2010, hlm. 494) ini menunjukkan keadaan yang "tidak kasar" (licin), iaitu "halus", masing-masingnya $5 \%$ dan $10 \%$ berdasarkan dapatan analisis. Ini juga sekali gus meningkatkan dominasi kata "lembut" menjadi $40 \%$. Sehubungan dengan itu kasus kecantikan telapak kaki dan tumit ini juga memperlihatkan keadaan yang sama seperti kecantikan kulit muka, kata yang berkolokasi tersebut saling berhubungan. Dalam kasus ini cantiknya telapak kaki dan tumit dikolokasikan dengan kulit kaki dan tumit antaranya dengan "lembut", "tidak keras", "tidak rosak" dan "halus" (Rajah 5). 


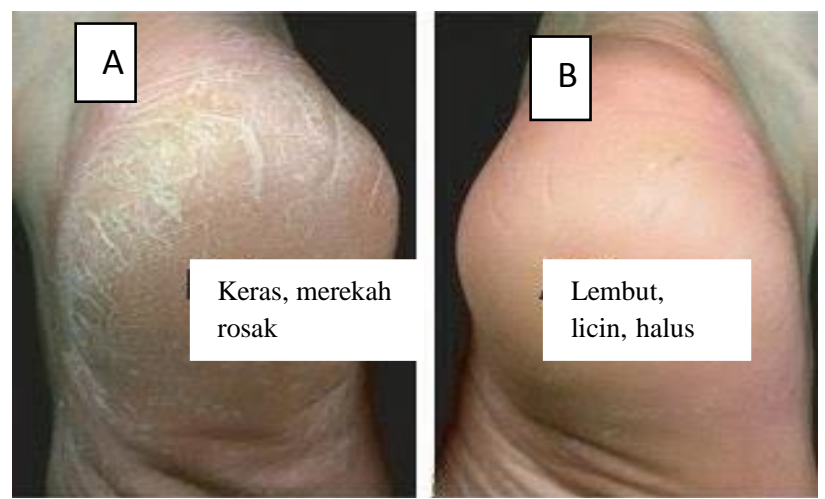

Rajah 5. Tumit kaki

Paparan Rajah 5 sering kali ditemui dalam iklan penjagaan kecantikan tapak kaki. Gambar B memperlihatkan fitur tapak kaki yang dilabelkan sebagai telapak kaki yang cantik, iaitu memiliki fitur lembut, licin dan halus. Sebaliknya tapak kaki yang permukaan kulitnya keras, iaitu kematu dengan permukaan kulit tapak kaki yang merekah dan pecah dianggap sebagai paparan yang hodoh, lihat gambar A. Ini cuba dielakkan bagi wanita yang menitikberatkan kecantikan dari hujung rambut sehingga ke hujung kaki. Lihat iklan spray kaki dalam Rajah 6 oleh D'herbs yang berikut:

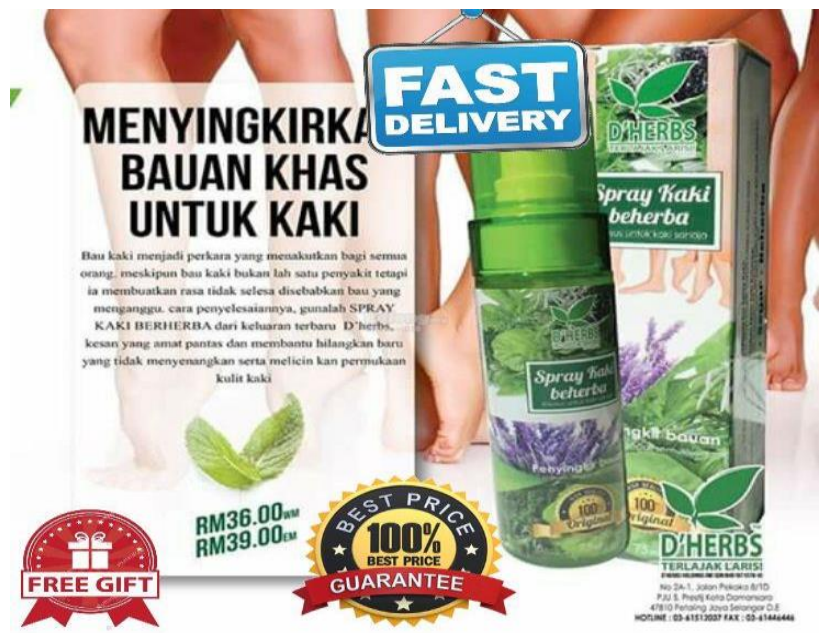

Fitur cantik untuk kaki dengan menggunakan spray - kaki tidak berbau dan melicinkan permukaan kulit kaki.

Rajah 6. Spray kaki berherba

\section{Kata mendefinisi kata cantik - bibir}

Jadual 3

Kolokasi kata cantik - Bibir

\begin{tabular}{llcc}
\hline Bil. & Bibir & Jumlah & Peratusan \% \\
\hline 1. & Merah & 4 & 22.2 \\
2. & Licin & 2 & 11.1 \\
3. & Lembut & 1 & 5.55 \\
4. & $\varnothing$ kering & 2 & 11.1 \\
5. & Lembap & 2 & 11.1
\end{tabular}




\begin{tabular}{llcl} 
6. & $\varnothing$ gelap & 1 & 5.55 \\
7. & $\varnothing$ menggelupas & 1 & 5.55 \\
8. & Berseri & 1 & 5.55 \\
9. & Penuh & 1 & 5.55 \\
10 & Anjal & 1 & 5.55 \\
11. & Mungil & 1 & 5.55 \\
12. & Sihat & 1 & 5.55 \\
\hline & Jumlah & 18 & $100 \%$ \\
\hline
\end{tabular}

Petunjuk: $\varnothing$ - tidak mempunyai fitur makna yang dirujuk

Jadual 3 menunjukkan kecantikan bibir dikolokasikan dengan 18 kata, iaitu dengan warna "bibir yang merah", secara dominannya menggambarkan bibir yang cantik, 22.2\%, "licin", " $\varnothing$ kering" dan "lembap", masing-masingnya 11.1\%. Terdapat hubungan sebab dan akibat dalam kasus ini juga, iaitu jika "bibir merah", ia bererti "tidak gelap", "lembut", " $\varnothing$ menggelupas", "sihat" yang setiap satunya 5.55\%. Ini secara langsung berhubung dengan warna bibir yang merah dan peratusan untuk sifat ini meningkat kepada $77.7 \%$. Sehubungan dengan itu tidak keterlaluan jika dikatakan bahawa bibir yang cantik memiliki fitur-fitur dominan yang tersebut. Lihat keadaan bibir dalam Rajah 7 yang berikut:

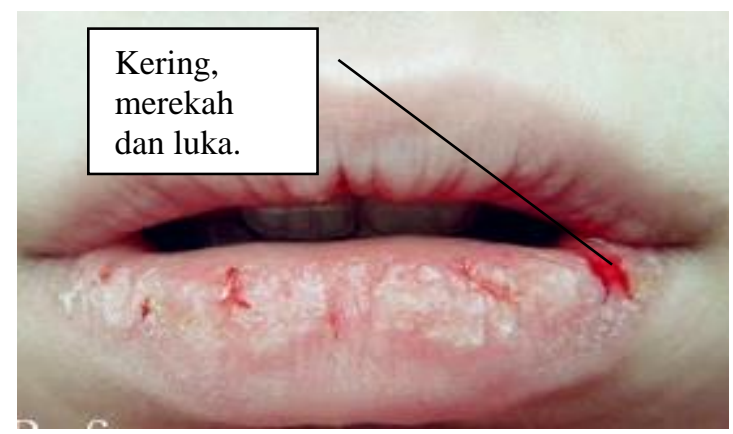

Rajah 7. Bibir kering, merekah dan luka

Bibir yang kering akan merekah dan menyakitkan selain akan kelihatan hodoh. Ini yang cuba dielakkan daripada berlaku. Sehubungan dengan itu kebanyakan produk penjagaan bibir menekankan khasiat produk yang dapat melembapkan bibir sekali gus menjadikan warna bibir merah serta kelihatan segar, lembut dan licin (Rajah 8). 


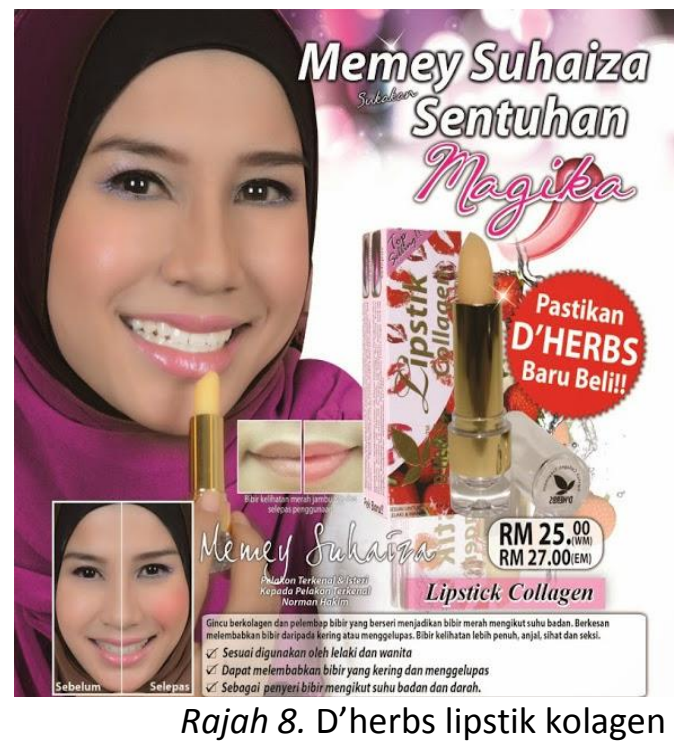

Fitur cantik dengan menggunakan lipstik kolagen bibir merah, bibir penuh, anjal, sihat dan melembabkan bibir.

\section{Kata mendefinisi kata cantik - rambut}

Jadual 4

Kolokasi kata cantik - Rambut

\begin{tabular}{llcc}
\hline Bil & Rambut & Jumlah & Peratusan \% \\
\hline 1. & Hitam & 3 & 9.7 \\
2. & Berkilau & 1 & 3.2 \\
3. & lebat & 6 & 19.4 \\
4. & menyerlah & 2 & 6.5 \\
5. & $\varnothing$ rambut gugur & 4 & 12.9 \\
6. & Kuat & 1 & 3.2 \\
7. & $\varnothing$ tidak jarang & 1 & 3.2 \\
8. & $\varnothing$ nipis & 1 & 3.2 \\
9. & $\varnothing$ beruban & 2 & 6.5 \\
10. & Bersinar & 3 & 9.7 \\
11. & Halus & 1 & 3.2 \\
12. & Segar & 1 & 3.2 \\
13. & $\varnothing$ mudah putus & 1 & 3.2 \\
\hline 14. & Bersih & & \\
& i. $\varnothing$ berkelemumur & 2 & 6.5 \\
& ii. $\varnothing$ gatal & 1 & 3.2 \\
& iii. Harum & 1 & 3.2 \\
\hline
\end{tabular}

Petunjuk: $\varnothing$ - tidak mempunyai fitur makna yang dirujuk

Jadual 4 menunjukkan kecantikan rambut dikolokasikan secara signifikan dengan enam kata, iaitu "lebat" (19.4\%), “Ø rambut gugur" (12.9\%), "hitam" serta "bersinar" (9.7\%), "menyerlah", " $\varnothing$ beruban" dan " $\varnothing$ berkelemumur" masingmasingnya (6.5\%). Kelebatan rambut yang bertitik tolak pada keadaan rambut yang 
tidak gugur menjadi fitur yang signifikan untuk wanita kerana rambut merupakan mahkota wanita. Keguguran rambut dalam kuantiti yang banyak, menjadikan rambut di kepala akan kelihatan sedikit dan nipis sehingga menampakkan kulit kepala. Keadaan kulit kepala yang jelas kelihatan akan menyebabkan kepala wanita dikatakan hampir botak. Ini sama sekali cuba dielakkan. Kata "lebat" dan "rambut tidak gugur" merupakan fitur yang dapat disekalikan, iaitu hubungan kesan akibat yang menjadikan peratusan meningkat kepada 32.3\%. Sementara itu, warna yang diinginkan bagi rambut ialah hitam, iaitu yang bertentangan dengan warna putih (beruban) yang dianggap lambang ketuaan. Dalam konteks kecantikan rambut, memiliki fitur rambut yang berwarna hitam sahaja tidak memadai. Rambut yang hitam ini juga perlu memiliki fitur bersinar dan fitur berkilau. Kedua-dua fitur ini diperlukan bagi menggambarkan kecantikan rambut. Dan kesan daripada rambut yang bersinar dan berkilau keadaan rambut ini akan menyerlah, iaitu menonjol. Selanjutnya, kesan penjagaan kecantikan rambut ini akan menjadikan kulit kepala sihat dan tidak mempunyai kelemumur. Kelemumur akan menyebabkan kegatalan kulit kepala. Kulit kepala yang berkelemumur akan menjejaskan kecantikan rambut. Kesemua kata yang berkolokasi ini memperlihatkan hubungan sebab akibat. Lihat Rajah 9 dan 10 yang memaparkan warna rambut yang hitam, lebat dan kuat. Kekuatan rambut (kekuatan akar rambut dan tekstur rambut) diperlihatkan dengan gambaran rambut yang boleh dipintal.

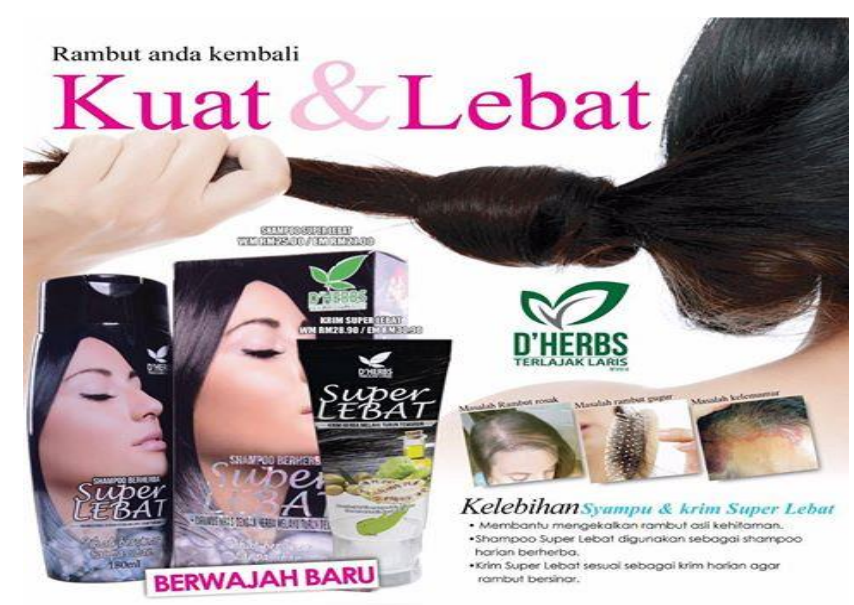

Fitur cantik dengan penggunaan syampu dan krim rambut: warna rambut hitam, bersinar, kuat dan lebat.

Rajah 9. D'herbs syampu rambut 


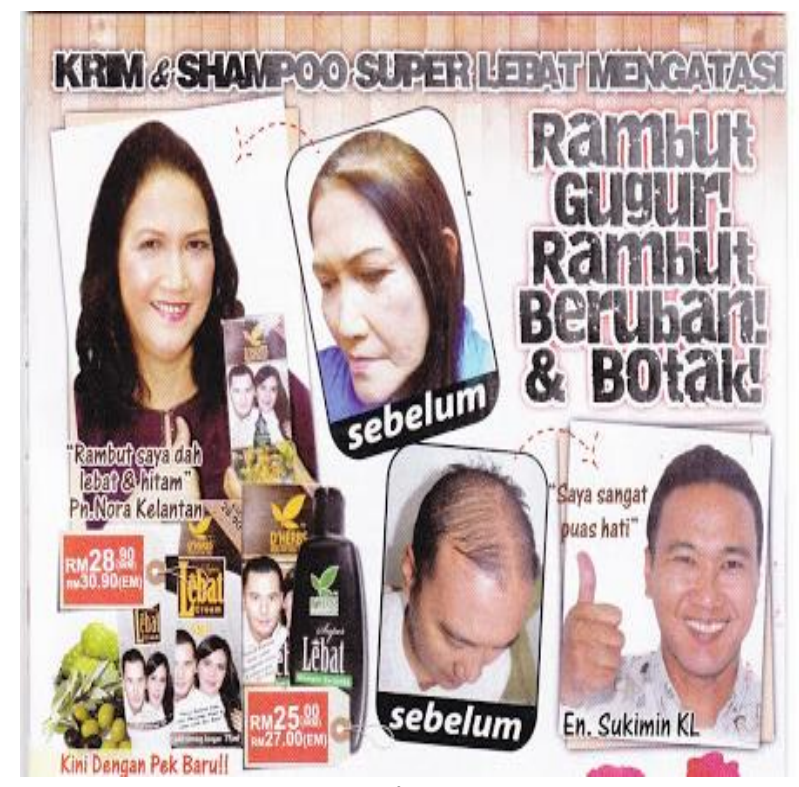

Fitur cantik dengan penggunaan krim dan syampu: rambut tidak gugur, rambut tidak beruban dan kepala tidak botak.

Rajah 10. D’Herbs krim dan syampu rambut

\section{Kata mendefinisi kata cantik - badan/anggota badan lain}

Jadual 5

Kolokasi kata cantik - badan/anggota badan lain

\begin{tabular}{llcc}
\hline Bil & Badan/ Anggota badan lain & Jumlah & Peratusan \% \\
\hline 1. & badan - langsing & 3 & 17.6 \\
2. & lengan dan peha - kecil & 1 & 5.9 \\
3. & pipi - runcing & 1 & 5.9 \\
4. & punggung - montok & 1 & 5.9 \\
5. & Slim & 2 & 11.8 \\
6. & Sihat & 1 & 5.9 \\
7. & Cerah & 1 & 5.9 \\
8. & Harum & 1 & 5.9 \\
9. & $\varnothing$ lemak & 2 & 11.8 \\
10. & Gebu & 2 & 11.8 \\
11. & Lembut & 1 & 5.9 \\
12. & Putih & 1 & 5.9 \\
\hline & Jumlah & 17 & $100 \%$ \\
\hline
\end{tabular}

Petunjuk: $\varnothing$ - tidak mempunyai fitur makna yang dirujuk

Jadual 5 menunjukkan kecantikan badan/anggota badan lain memperlihatkan kata "langsing" (17.6\%), "slim", " $\varnothing$ lemak" dan "gebu” (11.8\%) bagi fitur cantik yang dirujuk. "Langsing", "slim" dan " $\varnothing$ lemak" ini sebenarnya merujuk pada makna yang sinonim dan boleh disekalikan dengan dominasi 41.2\%. Sehubungan itu, fitur kecantikan badan yang diutamakan oleh wanita apabila berkaitan dengan bentuk badan ialah fitur "langsing" selain "gebu" (kulit) dan fitur- 
fitur lain seperti "putih", "montok" (mempunyai kepadatan tertentu), "kulit badan yang lembut", "pipi yang runcing", iaitu tidak tembam dan sebagainya (Rajah 11).

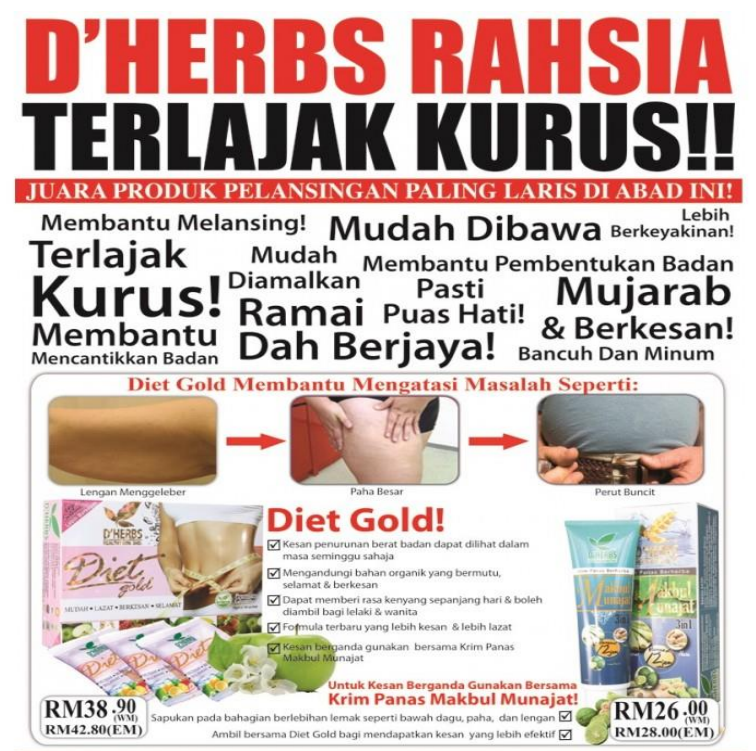

Fitur cantik dengan penggunaan krim: bentuk badan langsing, perut kempis, peha yang kecil, lengan yang tidak menggeleber.

Rajah 11. D’herbs suplemen dan krim

\section{Kata mendefinisi kata cantik - kuku}

Jadual 6

Kolokasi kata cantik - Kuku

\begin{tabular}{llcc}
\hline Bil & Kuku & Jumlah & Peratusan \% \\
\hline 1. & $\varnothing$ tidak bergaris & 1 & 20.0 \\
2. & $\varnothing$ kuning & 1 & 20.0 \\
3. $\varnothing$ rapuh/patah & 2 & 40.0 \\
4. & $\varnothing$ kering & 1 & 20.0 \\
\hline & Jumlah & 5 & $100 \%$ \\
\hline
\end{tabular}

Petunjuk: $\varnothing$ - tidak mempunyai fitur makna yang dirujuk

Jadual 6 menunjukkan kecantikan kuku secara signifikan dikolokasi dengan kata " $\varnothing$ rapuh/patah" (kuat), iaitu $40 \%$, diikuti dengan kata " $\varnothing$ tidak bergaris", “ $\varnothing$ kuning" dan " $\varnothing$ kering" berjumlah $20 \%$. Kecantikan kuku digambarkan dengan kuku yang tidak bergaris, tidak kuning, tidak rapuh dan tidak kering. Produk kecantikan kuku dapat dilihat pada produk seperti Rajah 12 berikut: 


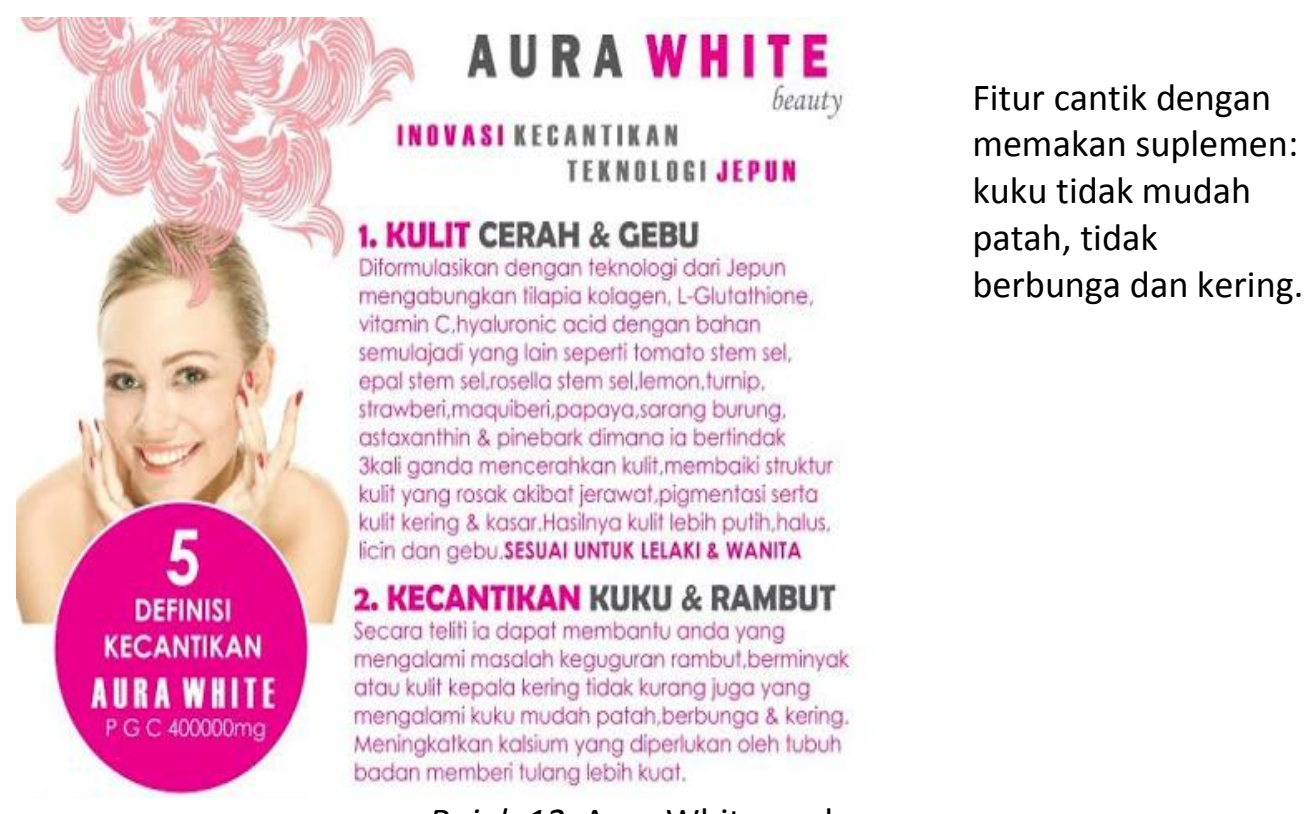

Rajah 12. Aura White suplemen

Keadaan kuku yang cantik dapat dilihat seperti Rajah 13 yang berikut:

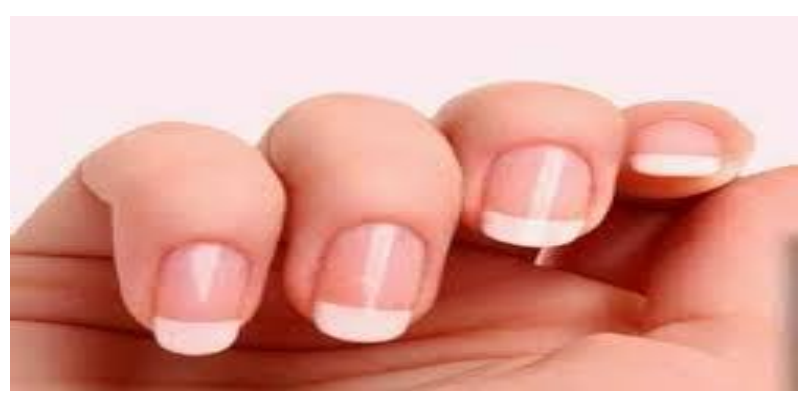

Rajah 13. Kuku Cantik

Sering kali penjagaan kecantikan kuku dilakukan di pusat rawatan kuku yang menyediakan rawatan pedicure dan manicure. Rawatan kecantikan kuku jari tangan seperti Rajah 14 yang berikut:

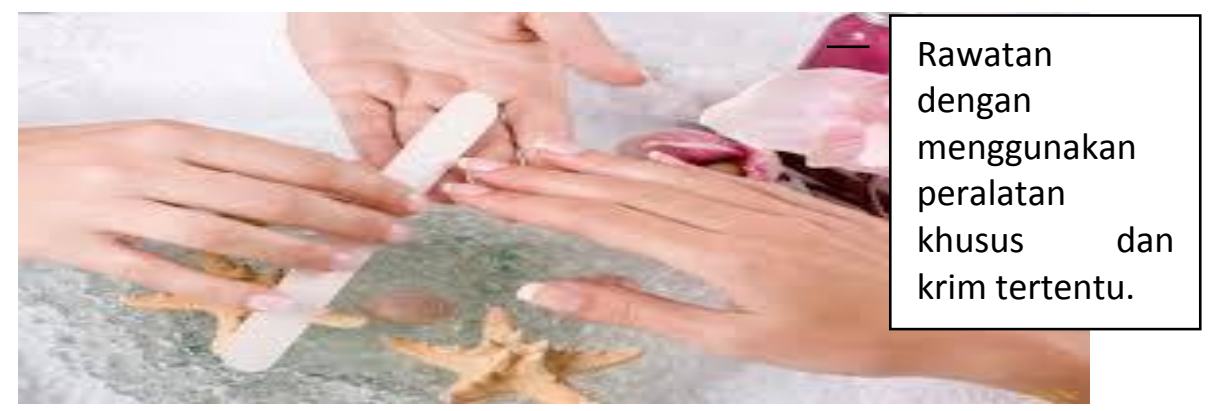

Rajah 14. Rawatan kuku

Kuku yang dianggap tidak cantik dapat dilihat seperti Rajah 15 yang berikut: 


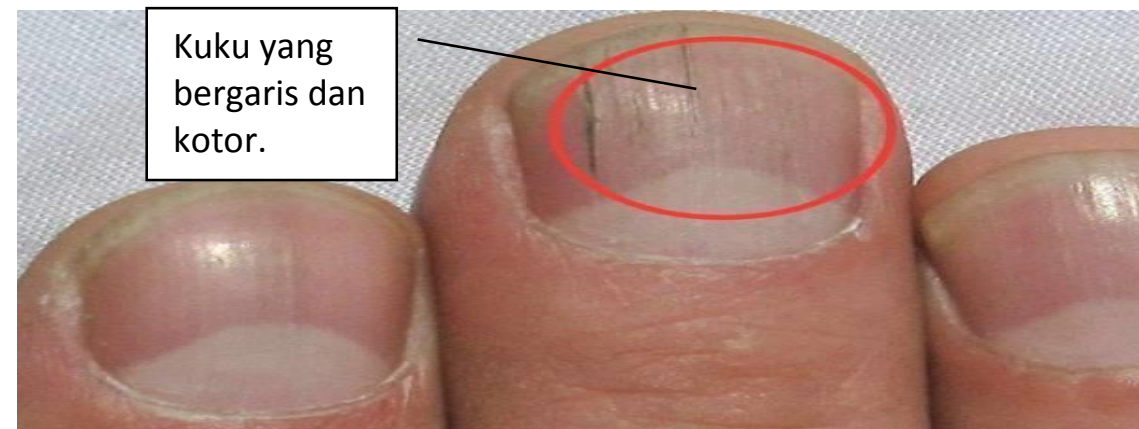

Rajah 15. Kuku hodoh

Kecantikan kuku dalam kalangan orang Melayu sering kali diperindah dengan penggunaan inai (henna). Ini kerana bagi orang Melayu yang beragama Islam pemakaian pewarna kuku tidak dibolehkan semasa solat. Produk henna juga ada dikeluarkan oleh syarikat produk kecantikan tempatan malahan ada yang diusahakan oleh orang perseorangan, iaitu yang dikenali sebagai inai segera (Rajah 16 dan 17).

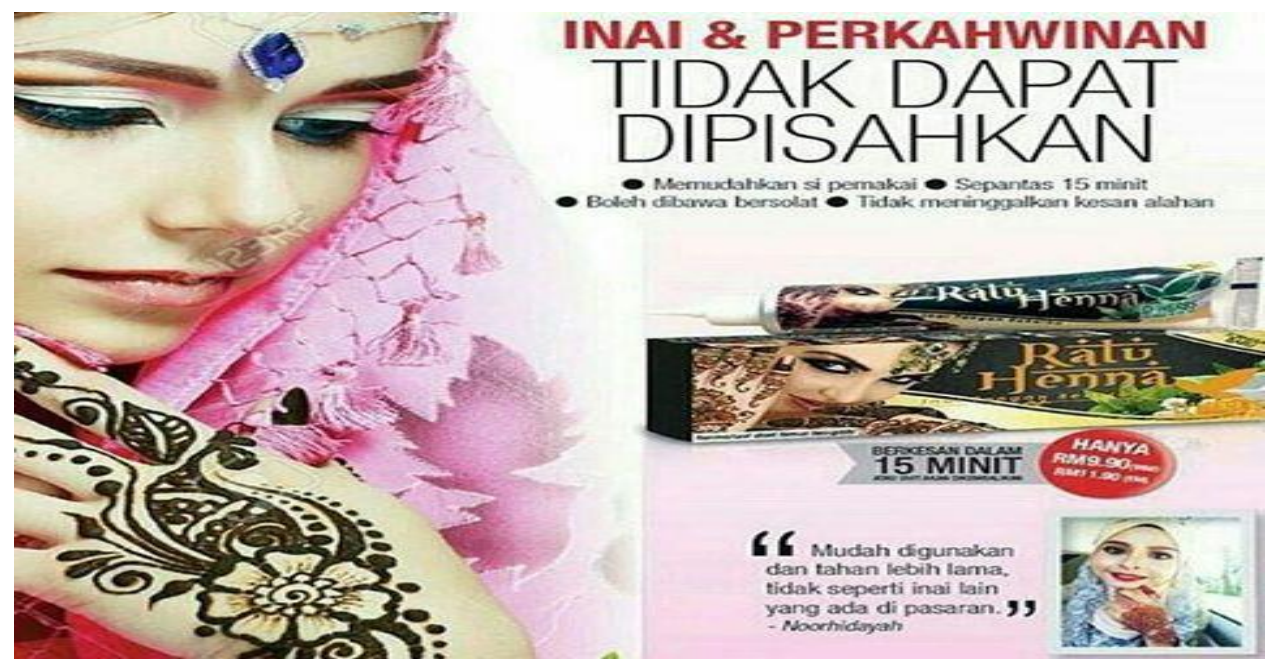

Rajah 16. D'herbs inai

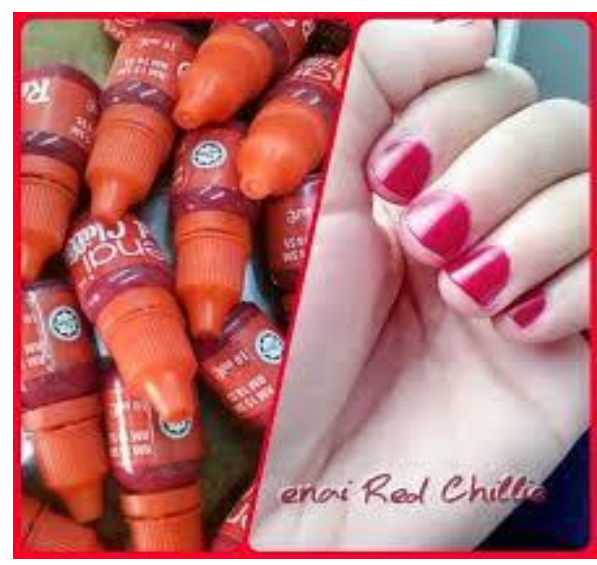

Rajah 17. Inai segera 
Dalam konteks ini kuku yang cantik juga dirujuk dengan fitur memberikan warna kepada kuku melalui penggunaan inai/henna bagi orang Melayu Islam. Dan dengan kecanggihan teknologi penghasilan inai/henna hari ini, inai/henna kini mempunyai warna-warna yang pelbagai sepertimana produk pewarna kuku keluaran syarikat luar negara.

Analisis yang dilakukan ini telah memperlihatkan hubungan sebab akibat antara kata-kata yang berkolokasi dan hubungan sebab akibat ini berasaskan tiga sumber deria manusia, iaitu deria lihat, deria rasa dan deria bau. Secara keseluruhannya dapatan analisis yang dilakukan ini telah memperlihatkan secara terperinci tentang rujukan kata cantik dengan kepelbagaian kolokasi kata yang berlaku berserta kecenderungan penggunaan kata. Kajian yang dilakukan sebelum ini hanya secara umum menyatakan kata cantik dan kolokasi kata tanpa memperlihatkan kecenderungan penggunaannya. Kajian ini juga telah memaparkan berlakunya pemilihan kata yang sinonim dan berulang kali digunakan selain penggunaan campur kod. Ini secara tidak langsung memperlihatkan kelaziman yang berlaku dalam kalangan pengguna bahasa Melayu yang rata-ratanya penutur dwibahasa. Hasil dapatan ini juga tidak memperlihatkan sebarang kecederungan makna kata cantik yang berkiblatkan barat sebagaimana dapatan kajian yang dilakukan oleh Shabudin dan Aman (2013b). Malahan tidak keterlaluan jika dikatakan dapatan ini bersifat tempatan, iaitu makna cantik dari perspektif Melayu dan selari dengan yang dibincangkan oleh Wirasari (2016) bahawa makna cantik berhubungan dengan budaya masyarakat setempat.

\section{Kesimpulan}

Definisi kata cantik dalam kamus tidak secara terperincinya memberikan fitur cantik yang dirujuk. Dalam mana-mana kamus bahasa Melayu, kata cantik diberikan definisi secara umum sahaja. Sehubungan itu apabila definisi kata ini diberikan secara umum maka ia bersifat subjektif. Ini bersesuaian dengan peribahasa Inggeris Beauty lies in the eyes of the beholder. Kamus memperlihatkan kekangan definisi makna yang dirujuk sementara peribahasa Inggeris pula meletakkan fitur cantik pada mata yang memandang. Walau bagaimanapun anggota masyarakat memperlihatkan kecenderungan fitur cantik pada pandangan majoriti khalayak. Pengguna bahasa Melayu dalam analisis ini telah memperlihatkan kecenderungan fitur kata cantik yang boleh dirujuk dan penggunaannya dalam konteks linguistik.

Dalam buku-buka sastera klasik digambarkan kecantikan seseorang wanita itu dengan analogi tertentu seperti hidung mancung dengan fitur bak seludang, dagu yang cantik dengan fitur bagai lebah tergantung, bibir merah dengan fitur bak delima merekah dan sebagainya. Fitur-fitur sebegini agak sukar ditafsir dan difahami khususnya oleh generasi muda mahupun pelajar bahasa. Oleh itu, pemahaman tentang fitur kata cantik perlu dilihat dalam konteks semasa, iaitu penggunaan kata cantik dalam konteksnya. Kewujudan banyak slogan, motto dan penghuraian khasiat produk kecantikan dalam iklan telah mempermudah definisi kata cantik melalui kolokasi kata yang digunakan dalam strategi pemasaran produk. Strategi pemasaran ini telah secara langsung menyenaraikan sejumlah kata-kata yang digunakan secara 
bersama-sama dengan kata cantik. Kata-kata yang dirujuk sebagai kolokasi ini telah memperlengkap definisi kata cantik yang dirujuk.

Dapatan analisis memperlihatkan definisi kata cantik pada wanita melibatkan tiga deria, iaitu lihat, rasa dan bau. Ketiga-tiga sifat deria ini merupakan hasil hubungan sebab dan akibat. Kecenderungan penggunaan kata yang berkolokasi ini juga memperlihatkan kasus perulangan makna yang sama, iaitu penggunaan kata yang bersinonim seperti langsing = slim = tidak ada lemak; hubungan sebab akibat, seperti tiada garis halus = tidak akan ada kedut; tidak ada masalah keguguran rambut = rambut lebat; flawless, maka tidak ada masalah kulit seperti jerawat, jeragat, pori-pori terbuka, tona kulit tak sekata dan sebagainya.

Dapatan analisis yang dilakukan ini tidak hanya membantu pelajar bahasa memahami dan menghubungkan fitur cantik yang dirujuk secara jelas tetapi juga memperlihatkan kesinoniman kata yang wujud dan digunakan. Tidak keterlaluan jika dikatakan bahawa dengan adanya kolokasi kata seperti ini, definisi kata cantik dapat difahami tanpa perlu melihat kamus lagi. Melalui analisis ini, fitur makna cantik telah diperlihatkan melalui tanggapan realiti sebenar masyarakat pengguna bahasa itu sendiri.

Data yang digunakan merupakan data iklan produk kecantikan tempatan. Sehubungan itu, dapatan ini telah memperlihatkan kolokasi bagi kata cantik bagi penutur natif bahasa Melayu dan orang Melayu. Dapatan ini hanya teraplikasi pada definisi kata cantik untuk wanita. Walaupun dapatan ini masih dianggap bersifat tentatif, sekurang-kurangnya dapatan ini telah berjaya menyelesaikan definisi kata cantik yang bersifat subjektif dan belum ditemui dalam mana-mana kamus yang pernah diterbitkan sebelum ini. Jumlah korpus yang lebih besar diperlukan bagi memperoleh dapatan yang boleh dipertanggungjawabkan.

Selain itu dalam memperkukuh dapatan yang sedia ada, kajian silang budaya juga boleh dilakukan kerana definisi kata cantik pasti berhubungan dengan budaya sesuatu masyarakat. Misalnya bagi budaya masyarakat etnik tertentu, makna cantik dirujuk sebagai memiliki leher yang panjang, berbibir tebal, badan bertatu dan sebagainya. Sehubungan dengan itu dicadangkan pada masa depan kajian difokuskan pada aspek ini selain tidak meminggirkan kajian makna kata kacak atau tampan yang kurang dilakukan.

\section{Rujukan}

Bahns, J., \& Eldaw, M. (1993). Should we teach EFL students collocations. System, 21(1), 101-114.

Berry, B. (2007). Beauty bias: Discrimination and social power. Wesport, CT: Praeger. Britton, A. M. (2012). The beauty industry's influence on women in society. Honors thesis and capstone, 86. Retrieved from http://schorlars.unh.edu/Honors/86

Channell, J. (1981). Applying semantic theory to vocabulary teaching. ELT, 35(2), $115-22$.

Etcoff, N., Orbach, S., Scott, J., \& D'Agostino, H. (2004). The real truth about beauty: A global report. (pp. 1-48). 
Goldman, A., \& Waymer, D. (2014). Identifying ugliness, defining beauty: A focus group analysis of and reaction to ugly Betty. The Qualitative Report, 19(10), 1-19. Retrieved from http://nsworks.nova.edu/tar/vol19/iss10/2.

Howarth, P. (1998). Phraseology and second language proficiency. Applied Linguistics, 19, 24-44.

Kamus Dewan (4th ed.). (2015). Kuala Lumpur, Malaysia: Dewan Bahasa dan Pustaka.

Lewis, M. (2000). Teaching collocation: Further developments in the lexical approach. Hove, England: LTP.

Matthews, P. H. (2007). Oxford concise dictionary of linguistics ( $2^{\text {nd }}$ ed.). Oxford: Oxford University Press.

McCarthy, M., \& O'Dell, F. (2005). English collocations in use. Cambridge: Cambridge University Press.

Mohd Salleh, N. S., \& Musa, H. (2016). Kepelbagaian makna leksikal dalam iklan produk kecantikan. Pertanika Mahawangsa, 3(1), 25-36.

Nesselhauf, N. (2003). The use of collocations by advanced learners of English and some implications for teaching. Applied Linguistics, 24, 223-242.

Richards, J. C. (1976). The role of vocabulary teaching. TESOL Quarterly, 10(1), 77-89.

School of Physical Sciences. (2015). E-FIT team define the face of beauty. Retrieved from https://www.kent.ac.uk/physical-sciences/news/front-page/efitbeauty.html

Shabudin, M., \& Aman, I. (2013a). Interdiskursiviti dalam wacana iklan produk kecantikan berbahasa Jepun. GEMA Online Journal of Language Studies, 12(3), 149-168.

Shabudin, M., \& Aman, I. (2013b). Wacana dan ideologi iklan produk kecantikan berbahasa Jepun. GEMA Online Journal of Language Studies, 12(3) Special Edition, 789-816.

Sidik, F. (2012). Kata kerja dalam slogan iklan kecantikan wanita: Analisis semantik leksikal. (Unpublished Master's Dissertation). University of Malaya, Kuala Lumpur, Malaysia.

Tesaurus Bahasa Melayu Dewan. (2000). Kuala Lumpur, Malaysia: Dewan Bahasa dan Pustaka.

Wirasari, I. (2016). Kecantikan kaum perempuan dalam iklan. Demandia Journals of Telkom University, 1(2), 146-156.

Webb, S., \& Kagimoto, E. (2009). The effects of vocabulary learning on collocation and meaning. TESOL Quarterly, 43(1), 55-77.

Zahid, I., \& Sidik, F. (2012). Analisis komponen makna kata kerja dalam slogan iklan produk kecantikan wanita. Jurnal Bahasa, 12(2), 256-283.

Zahid, I. (2017). Menyempurnakan kata menyampaikan makna: Pengajaran dan pembelajaran (P\&P) aspek kolokasi dalam medan makna. Paper presented at the Menyempurnakan Kata Menyampaikan Makna Seminar Bahasa Melayu 2017 Singapura.

Sumber Data:

Facebook

Aurawhite Beauty. (2013). Aurawhite Beauty. Retrieved 5 November 2017, from 
https://www.facebook.com/AuraWhiteBeautyAura/

D'herbs Holdings Sdn .Bhd. (2015). D'herbs Holdings Sdn. Bhd Terlajak Laris. Retrieved 5 November 2017, from https://www.facebook.com/pg/ dherbsholdingsdnbhd/

Empayar Dato' Seri Vida HQ. (n.d). Empayar Dato' Seri Vida. Retrieved 5 November 2017, from https://www.facebook.com/pg/empayarbeautyDATOSERIVIDA/

\section{Imej dari blog, laman sesawang dan Facebook}

Rajah 2: Norwan. (n.d.). Glow B White. Retrieved from http://norwancollection.blogspot.com/2016/06/rm-35.html

Rajah 3: Beauty Bella Nara. (n.d.). Retrieved from http://beautybellanara.blogspot.com/p/qu-puteh-vida-beauty.html

Rajah 4: $\quad$ Rus, N. M. (2016). Millenia Whitening Champ. Retrieved from http://www.aurabeautynet.com/2016/01/millenia-whiteningchamp.html

Rajah 5: $\quad$ Athidean. (2014). Tips hilangkan tumit kaki merekah/kasar: Scholl Rough Skin Remover. Retrieved from http://cheerisheverycherry.blogspot.com/2014/09/tips-hilangkantumit-kaki-merekahkasar.html

Rajah 6: D'herbs Healthy Sdn.Bhd. (2017). D'herbs Online. Retrieved 5 November 2017, 2017, from https://www.facebook.com/DHerbsOnline/

Rajah 7: Redaksi one Z. (2016). Retrieved from http://redaksionez.blogspot.com/2016/08/menyingkirkan-bibirpecah-pecah.html

Rajah 8: $\quad$ Redaksi one Z. (2016). Retrieved from http://redaksionez.blogspot.com/2016/08/menyingkirkan-bibirpecah-pecah.html

Rajah 9: $\quad$ Kiosk, B. (2013). Shampoo Berherba Super Lebat D'Herbs Retrieved from https://beauty-kiosk.blogspot.com/2013/02/super-lebatshampoo-berherba-dherbs.html

Rajah 10: Herbs, N. (2013). Herbs Pewarna Rambut Super Lebat. Retrieved from http://nisaherbs.blogspot.com/2013/12/dherbs-pewarnarambut-super-lebat.html

Rajah 11: D'herbs Healthy Sdn.Bhd. (2017). D'herbs Rahsia Terlajak Kurus. Retrieved 5 November 2017, from https://deherbs.com.my/testimoni-pelanggan/

Rajah 12: $\quad$ Ct.Sophie.Phea. (2013). Aura White L-Glutathione Collagen 900000 $\mathrm{mg} \quad$ Retrieved from http://sophiesbeautyoutlet.blogspot.com/2013/07/aura-white-lglutathione-collagen-900.html

Rajah 13: $\quad$ Trik Memiliki Kuku Yang Cantik. (2015). Retrieved from http://cantiksiapsedia.blogspot.com/2015/03/trik-memiliki-kukutangan-yang-cantik.html 
Rajah 14: A Day Away Salon Spa. (2017). Spa Manicure. Retrieved 5 November 2017, from https://adayawaysalonandspa.com/product/spa-manicure/

Rajah 15: Amahoru, I. K. (2017). Kuku Anda Bergaris Hitam? Itu Petanda Kanker. Retrieved 5 November 2017, from http://health.rakyatku.com/read/67459/2017/09/29/

Rajah 16: Zaki, A. M. (2017). Inai \& Perkahwinan. Retrieved 5 November 2017, from http://www.thepicta.com/tag/ratuhennadherbs

Rajah 17: Mummy.zie.9. (2017). Enai Red Chillie. Retrieved 5 November 2017, from https://sg.carousell.com/p/enai-red-chillie-15683732/

Instagram : Data bentuk teks

aliffsyukriterlajaklaris.(2018, Mac 23). Siapa nak cuba garennty elok ... . Retrieved from https://www.instagram.com/p/BgqFurknKsp/

aliffsyukriterlajaklaris.( 2018, Mac 22). Sumpah saya pakai memang berkesan ... . Retrieved from https://www.instagram.com/p/BgneeXdB Ol/

aliffsyukriterlajaklaris. (2018, Mac 6). Pewarna rambut yang paling berkesan ... . Retrieved from https://www.instagram.com/p/Bf-P9OCnllV/

aliffsyukriterlajaklaris. (2018, Mac 5). Ada panau, kayap smua boleh sembuh ... . Retrieved from http://www.instagram.com/p/Bf7GananZ9/

aliffsyukriterlajaklaris. (2018, Januari 10). Siapa pernah cuba saya nak buat giveway ...Retrieved from https://www.instagram.com/p/BdwwsPhH58a/

aliffsyukriterlajaklaris.(2017, November 16). Terjual lebih 100 ribu botol.... Retrieved from https://www.instagram.com/p/BbibRgBncTu/

aliffsyukriterlajaklaris.(2017, Disember 1). Pewarna rambut inai paling terlajak laris ... . Retrieved from https://www.instagram.com/p/BcKHgNKHD3H/

aliffsyukriterlajaklaris. (2017, Oktober 26). Dulu saya ada masalah kulit kusam... . Retrieved from http://www.instagram.com/p/BasZubaHMtz/

aliffsyukriterlajaklaris. (2017, Oktober 15). Kadang2 orang muka hensem, tapi ketiak ... . Retrieved from https://www.instagram.com/p/BaRZRvInOA6/

aliffsyukriterlajaklaris. (2017, Oktober 4).Rambut gugur, beruban, gatal sy dah.... Retrieved from https://www.instagram.com/p/BZzvmSvn4qZ/

datoserivida. (2017, Disember 26).*_MALU rr NAK MAKAN KENDURI .. COVERCOVER... Retrieved from https://www.instagram.com/p/BdKuebShCQ2/ datoserivida (2017, September 6). Senyum .. la senyum... Ahai cek mek molek... Retrieved from https://www.instagram.com/p/BYr6VpehGRm/

datoserivida. (2017, September 4).Terputeh in 10 days? Flowless .. Licin.. seperti telur? ... Retrieved from https://www.instagram.com/p/BYn 3UehBHr/

datoserivida. (2017, September 2). Cara mudah bg sexy lips ... muka runcing ... Retrieved from https://www.instagram.com/p/BYiyx65BXgn/

datoserivida. (2017, Jun 3).Bole buat NYULOH muka Kita guna Qu Puteh Supra ... Retrieved from https://www.instagram.com/p/BU34dlnhX r/ 